\title{
Stress Indicator, Carcass Composition, and Meat Cholesterol of Kampung-Broiler Crossbred Chicken Treated By Different Stocking Density
}

\author{
Bayu Adhitya Nugraha ${ }^{1}$, Rudi Afnan ${ }^{2}$, Sri Darwati ${ }^{2}$, and Tuti Suryati ${ }^{2}$ \\ ${ }^{1}$ Graduate School of Animal Science, Bogor Agricultural University \\ ${ }^{2}$ Faculty of Animal Science, Bogor Agricultural University \\ Jl. Agatis, Darmaga Campus, Bogor 16680 - Indonesia \\ *Corresponding author: bayuadhitya14@yahoo.com
}

\begin{abstract}
This study aimed to investigate the effect of stocking density on stress indicator, carcass compositition, and meat cholesterol content of kampung-broiler crossbred chicken. A total of 90 DOCs of crossbred kampung-broiler (KB) were placed into 9 blocks of housing each with $1 \times 1 \mathrm{~m}^{2}$ in semi closed house that consist of 3 stocking densities 8,10 and 12 birds $\mathrm{m}^{-2}$ and respectively 3 replicates. The chickens were fed commercial broiler feed. Approximately $\pm 30 \%$ roosters slaughtered for analysis of malondialdehyde, carcass quality, and meat cholesterol. Malondialdehyde, carcass composition, and meat cholesterol was completely randomized designed with different stocking densities treatments and three replicates. Data was analyzed using analysis of variance (ANOVA) and had previously been tested for requirement of variance test assumption. Data of temperature humidity index (THI) was descriptively explained. The results showed that the effect of different stocking densities on stress indicator reflected by THI value and MDA content, carcass composition (percentage of carcass and abdominal fat weight), and cholesterol level were not significant. The different of stocking densities $\left(8,10\right.$ and 12 birds $\left.\mathrm{m}^{-2}\right)$ did not affect the stress indicators reflected by THI and MDA level, carcass composition and meat cholesterol level. Kampung-broiler crossbred chicken could develop at 8,10 or 12 birds $\mathrm{m}^{-2}$ densities since the lower of abdominal fat and meat cholesterol were resulted.
\end{abstract}

Key words: kampung-broiler crossbred chicken, stress indicator, carcass composition, meat cholesterol, stocking density

Abstrak. Penelitian ini bertujuan untuk menganalisis pengaruh tingkat kepadatan kandang ayam terhadap indikator stres, komponen karkas, serta kolesterol ayam persilangan kampung dan ras pedaging (KB). Sebanyak 90 ekor DOC ayam persilangan kampung dan ras pedaging (KB) digunakan dalam penelitian ini. Ayam KB ditempatkan pada 9 petak (ukuran $1 \times 1 \mathrm{~m}^{2}$ ) pada kandang semi closed house dengan 3 perlakuan. Setiap perlakuan dilakukan ulangan sebanyak 3 kali. Perlakuan kepadatan kandang yang berbeda yaitu 8,10 dan 12 ekor $\mathrm{m}^{-2}$. Pakan yang diberikan pada ayam merupakan pakan komersial ayam pedaging. Ayam jantan sebanyak $\pm 30 \%$ dipotong untuk analisis malondialdehida, kualitas karkas, dan kolesterol daging. Percobaan untuk penelitian malondialdehida, kualitas karkas, dan kolesterol daging menggunakan rancangan acak lengkap (RAL) dengan perlakuan kepadatan kandang berbeda. Temperature humidity index (THI) dibahas secara deskriptif. Data yang diperoleh dianalisis ragam ANOVA (Analysis of Variance) dan sebelumnya telah dilakukan pengujian untuk asumsi syarat pengujian ragam. Hasil penelitian menunjukkan perbedaan tingkat kepadatan kandang ayam persilangan kampung dan ras pedaging tidak berbeda nyata pada indikator stres (THI dan MDA), komponen karkas (persentase bobot karkas dan lemak abdomen), dan kadar kolesterol ( $>0.05)$. Kepadatan kandang $\left(8,10\right.$ dan 12 ekor $\left.\mathrm{m}^{-2}\right)$ tidak mempengaruhi indikator stres dilihat dari THI dan tingkat MDA, komposisi karkas, dan kadar kolesterol daging. Persilangan ayam kampung dan ras pedaging pada kepadatan kandang 8, 10 atau 12 ekor $\mathrm{m}^{-2}$ menghasilkan lemak abdomen dan kolesterol daging yang rendah.

Kata kunci : Persilangan ayam kampung dan ras pedaging, indikator stres, komposisi karkas, kolesterol daging, kepadatan kandang

\section{Introduction}

Kampung chicken belongs to Indonesian native chicken. The appearance, genetic trait, and spread of kampung chicken are very diverse and extensive. Kampung chicken has enormous potentials in contributing to food production (meat and eggs), nutrition, and income for 
farmers. As a meat producer, it has a commercial potention to develop because of its preference by some communities in Indonesia.

The development of kampung chicken in Indonesia does not significantly increase for several years. Population of kampung chicken in Indonesia has increased 0.60\% from 2014. But, it is still very low compared with broiler that reached $3.76 \%$ in 2014-2015 (BPS, 2015). This is caused by low productivity of kampung chicken and has not developed optimally. The growth efficiency of chicken and broiler is very different, kampung chicken reaches $900 \mathrm{~g}$ of body weight in 10 weeks (Aryanti et al., 2013) while broiler of Cobb strain can reach $2770 \mathrm{~g}$ in 7 weeks (Daryono et al., 2010).

Crossbreeding can increase meat production. This method, in short term, will increase the average of chicken body weight and carcass weight rapidly (Kgwatalala et al., 2015). The kampung chicken is crossed with broiler to improve the performance resulting from genetic combination of them.

Broilers very effective meat producer chickens. Broiler has a shorter production cycle than other commercial poultries because of a better genetic trait, especially for growth character. Broiler has a tender meat, large body size, high feed efficiency and very rapid weight gain. With these advantages, it still need a good maintenance to achieve the desired results, such as good meat weight and food security.

The stocking density optimization is one of the concerned. Inappropriate density results abnormal growth and high feed conversion and development deviances such as pecking each others, cannibalism, reduced feed intake, stress due to heat, and lead to death. Three different densities of stocking conducted by Asaniyan (2014) resulted the effect on body weight gain, feed conversion and carcass weight percentage. According to Kusnadi (2010) heat stress caused by temperature difference in the cage affects malondialdehyde level of broiler lever. The kampung-broiler crossbreeding is expected to produce the performance of two combinated gene, such as higher carcass quality and lower meat cholesterol and malondialdehyde MDA, were placed in different stocking densities.

\section{Materials and Methods}

\section{Experimental design}

The samples used were crossed Kampung chicken (males 12 birds) and Cobb broiler (Female 72 birds) with ratio male and female 1:6. The produced eggs were collected with a week intermittent for two periods. The eggs from each period were hatched in a machine for 21 days. A total number of 90 heads DOC unsexed were placed in three units of stocking with different densities, in three units of pen measuring $1 \times 1 \mathrm{~m}^{2}$. There were 3 cage, each cage cointained 3 pen $(1 \times 1 \mathrm{~m})$ and Each pen in cage was filled with 8,10 , and 12 birds. The data of temparature humadity indeks (THI) was collected at ages of 3-12 week. At the end of maintenance in week-12, an amount of $30 \%$ roosters from each pen were slaughtered for analysis of carcass composition. The meat from chests were taken homogeneously for meat cholesterol analysis, while livers and kidneys for analysis of MDA.

\section{Variables}

Stress indicators, i.e. THI (temperature humidity index) and malondialdehyde (MDA) level in liver and kidney. Carcass composition of chicken, i.e. weight percentages of carcass, bone, flesh, skin and abdominal fat. Meat cholesterol of chicken, i.e. meat cholesterol along chest and skin.

THI (Tao and Xin, 2003): THI was measured using a dry-wet bulb thermometer installed at $50 \mathrm{~cm}$ height from the pen floor. Data were taken three times a day (07:00, 12:00 and 17:00). THI was calculated using a formula as follows:

$$
\mathrm{THI}=0.85 \mathrm{Tdb}+0: 15 \mathrm{TWB}
$$

Where $\mathrm{THI}$ is temperature-humidity index $\left({ }^{\circ} \mathrm{C}\right)$; $\mathrm{T}_{\mathrm{db}}$ is dry-bulb temperature $\left({ }^{\circ} \mathrm{C}\right) ; \mathrm{T}_{\mathrm{WB}}$ is wet-bulb 
temperature $\left({ }^{\circ} \mathrm{C}\right)$

Malondialdehyde (MDA): MDA level was measured from liver and kidney and analyzed by spectrophotometer in accordance with modification of procedure Khan et al. (2012) an amount of $1.25 \mathrm{~g}$ of liver and kidney was chopped in cold conditions, homogenized in 5 $\mathrm{mL}$ of PBS (phosphate buffer saline) contained $11.5 \mathrm{~g} \mathrm{KC1/L}$. The homogenate was centrifuged at $4500 \mathrm{rpm}$ for 10 minutes. Analyses were performed according to Singh et al. (2002) with modification to TBA number counting by using 1,1,3,3-tetraetoxyprophane (TEP) (Sigma Aldrich, USA) as standard on gradually concentrations $(2,4,6,8$ and $10 \mu \mathrm{M})$.

Carcass composition (Nikmaram et al., 2013). Carcass percentage: Carcass is part of the chicken's body excludes blood, feathers, feet, head, neck, and all the viscera except liver, gizzard and heart (Antari et al., 2015). Carcass percentage was obtained by weighing the end of the chickens at the end of the research by taking a sample $\pm 30 \%$ chickens from each pen. Chickens were slaughtered, plucked and weighed for carcass weight. The equation was as follows:

Carcass percentage $=\frac{\text { Carcass weight }(\mathrm{g})}{\text { Alive weight }(\mathrm{g})} \times 100 \%$

Bone percentage: Bone percentage was obtained by weighing carcass weight of chest, upper thigh and lower thigh. Each carcass section was separated for skin and flesh. Bone percentage was obtained by the following equation:

$$
\text { Bone percentage }=\frac{\text { Bone weight }}{\text { Carcass weight }} \times 100 \%
$$

Meat percentage: Meat percentage was obtained by weighing carcass weight of chest, upper thigh and lower thigh. Each carcass section was separated for skin and flesh. Meat percentage was obtained by the following equation:

Meat percentage $=\frac{\text { Meat weight }}{\text { Carcass weight }} \times 100 \%$
Skin percentage: Skin percentage was obtained by weighing carcass weight of chest, upper thigh and lower thigh. Each carcass section was separated for skin and flesh. Skin percentage was obtained by the following equation:

$$
\text { Skin percentage }=\frac{\text { Skin weight }}{\text { Carcass weight }} \times 100 \%
$$

Abdominal fat percentage (Sarwono, 2013): Abdominal fat was measured by weighing fat obtained from around gizzard and sticked layers between abdominal muscles and intestines. Abdominal fat percentage was obtained by the following equation:

Abdominal fat $\%=\frac{\text { Abdominal fat weight }}{\text { Alive weight }} \times 100 \%$

Analysis of cholesterol (AOAC, 2005): Meat cholesterol level was measured using method of AOAC (2005) with a high temperature of saponification, in which the unsaponificated was extracted with toluene. Then, it was derivatizated into trimethylsilyl (TMS) and calculated using chromatography gas. Chromatography gas analysis was conducted by entering $1 \mathrm{~mL}$ of sample into chromatograph gas. The highest cholesterol area was determined by digital integrator for 16-18 minutes. The highest cholesterol area was divided by the highest internally cholesterol area standard to get the standard response ratio. The standard response was plotted to 4 highest standards $\left(0.01-0.20 \mathrm{mg} \mathrm{mL}^{-1}\right)$ to the cholesterol concentration. Derivatization was measured by the equation:

$$
\text { g sample } / m L \text { derivatization }=\left(W_{1} / V_{1}\right) \times\left(V_{2} / V_{3}\right)
$$

Where $\mathrm{W} 1$ is weight of the sample (g); V1 is Volume of toluene $(100 \mathrm{~mL})$ used in the extraction; V2 is aliquots of extract ( $25 \mathrm{~mL})$; V3 is volume of DMF used to dissolve the residue.

The sample weight per derivatisation volume was then employed for cholesterol level $\mathrm{mg}$ cholesterol/100 g sample, calculated by the equation: 
$\underline{\mathrm{mg} / \mathrm{mL} \text { sample cholesterol from standar curve } \times 100}$ gram sample/mL derivatization

Statistical Analysis: The experimental design used for carcass quality, MDA, and cholesterol is a completely randomized design (CRD). The obtained data were analyzed using analysis of variance (ANOVA) and had previously been tested for requirement of variance test assumption (Matjjik dan Sumertajaya 2013). The significant treatment was followed by Tukey test.

\section{Results and Discussion}

\section{Stress Indicators}

THI (Temperature humidity index) of Stocking. Wet-and-dry temperature is one of the important factors directly affecting to carcass and meat quality of livestock. Temperature wet and dry temperature determines the value of $\mathrm{THI}$ (temperature humidity index) and environmental enclosures livestock. The results show that THI averages for all treatments are not significantly different (Table 1).

The relatively same THI makes it possible to maintain on the density of 12 birds This may be caused by a proper use of exhaustfan, resulting in the optimum air circulation that affect to the same evaporation, induction, radiation and conversion for three different densities, causing a relatively same water vapor in stockings.

This hybrid chicken is homeotherm, which could keep the body temperature constantly in different density, making the body function takes place optimally. Chickens performed the same heat loss through evaporation, induction, radiation, and conversion for three different densities, causing the relatively same water vapor condition. This is in line with (Tao and Xin, 2003) stated that the effective environment temperature is within the zone termoneutral, then adults of broiler will maintain the body temperature between $41.2-42.2{ }^{\circ} \mathrm{C}$ through thermoregulation with minimal effort.

Malondialdehyde (MDA). Malondialdehyde (MDA) is the end-product of lipid peroxidation and usually used as a biological biomarker for oxidative stress assessment. The results showed the insignificant effect of liver and kidney malondialdehyde level of chicken with different densities (Table 2).

Malondialdehyde level in the liver was higher than kidney, proves liver as the most frequently oxidation process. A study of Zheng et al., (2016) found the broiler maintained for 20 days as a control with the density of 8 birds $\mathrm{m}^{-2}$ generated malondialdehyde level of 17.86 $\mathrm{nmol} \mathrm{mL}^{-1}$. The average result generated by three different treatments shows the same

Table 1 Temperature Humidity Indeks (THI) of stocking in different densities

\begin{tabular}{cccc}
\hline \multirow{2}{*}{ Week(s) } & \multicolumn{3}{c}{ Temperature Humidity Indeks $(\mathrm{THI}){ }^{\circ} \mathrm{C}$} \\
\cline { 2 - 4 } & $\mathrm{R} 1$ & $\mathrm{R} 2$ & $\mathrm{R} 3$ \\
\hline 3 & $29.56 \pm 1.19$ & $30.04 \pm 1.45$ & $30.15 \pm 1.59$ \\
4 & $28.23 \pm 1.27$ & $29.42 \pm 1.62$ & $28.95 \pm 1.35$ \\
5 & $28.58 \pm 1.42$ & $28.96 \pm 1.62$ & $28.70 \pm 1.66$ \\
6 & $28.40 \pm 1.66$ & $28.78 \pm 1.84$ & $28.67 \pm 1.67$ \\
7 & $28.30 \pm 1.63$ & $28.80 \pm 1.85$ & $28.54 \pm 1.43$ \\
8 & $28.60 \pm 1.56$ & $28.81 \pm 1.47$ & $28.24 \pm 1.36$ \\
9 & $28.49 \pm 1.50$ & $28.78 \pm 1.54$ & $29.08 \pm 1.47$ \\
10 & $28.52 \pm 1.36$ & $28.93 \pm 1.65$ & $28.72 \pm 1.44$ \\
11 & $28.36 \pm 1.38$ & $28.85 \pm 1.69$ & $28.70 \pm 1.41$ \\
12 & $28.42 \pm 1.50$ & $28.69 \pm 1.60$ & $28.75 \pm 1.70$ \\
\hline
\end{tabular}

Description :R1: Stocking density of 8 birds $\mathrm{m}^{-2}$; R2: Stocking density of 10 birds $\mathrm{m}^{-2}$; R3: Stocking density of 12 birds $\mathrm{m}^{-2}, \mathrm{THI}$ : Temperature humidity indeks 
Bayu Adhitya Nugraha et al./Animal Production. 18(3):149-156, September 2016

Accredited by DGHE No. 81/DIKTI/Kep./2011. ISSN 1411-2027

Table 2 Average of liver and kidney malondialdehyde (MDA) level in different stocking

\begin{tabular}{lccc}
\hline \multirow{2}{*}{ Number of MDA } & \multicolumn{3}{c}{ Treatment } \\
\cline { 2 - 4 } & $\mathrm{R} 1$ & $\mathrm{R} 2$ & $\mathrm{R} 3$ \\
\hline Liver MDA nmol per $\mathrm{mL}$ & $20.73 \pm 4.55$ & $17.69 \pm 7.65$ & $12.79 \pm 2.51$ \\
Kidney MDA nmol per $\mathrm{mL}$ & $17.33 \pm 8.14$ & $15.21 \pm 2.16$ & $11.56 \pm 3.54$ \\
\hline Description: R1: Stocking density of 8 birds $\mathrm{m}^{-2} ; \mathrm{R} 2:$ Stocking density of 10 birds $\mathrm{m}^{-2} ;$ R3: Stocking density of 12 birds \\
$\mathrm{m}^{-2}$, MDA: Malondialdehyde
\end{tabular}

relative MDA compared to broiler. The relatively same densities that also shows no difference of $\mathrm{THI}$ on each pen is suspected as a factor for the exceed-free radical absence, meaning that heat stress in each pen showed no oxidative stress. This is in accordance with Wu et al., (2015) which shows the no effect of liver malondialdehyde level of 21-days and 42-days control treatment broiler maintained with stocking density of 8 birds $\mathrm{m}^{-2}$. In case of heat stress among treatment cage density may affect the levels of malondialdehyde due to an increase in oxidative stress. This is also in line with Kusnadi (2009) that found the different temperatures of heat stress affected to malondialdehyde level due to an oxidative stress increase, means an existence of exceed free radicals than antioxidants.

\section{Carcass composition}

Carcass Weight Percentage and Abdomen Fat Percentage. Carcass is the livestock bodyweight after slaughtering excluded head, blood and internal organs, and feet and feathers. Abdominal fat is the fat contained in around the gizzard and attached layer between abdominal muscles and intestines. Results showed the carcass weight and abdominal fat are not significantly different for densities examined (Table 3).

The average of carcass weight percentage obtained is ranged $69.72-70.26 \%$ birds $^{-1}$ and the abdominal fat percentage ranged $1.52-1.82 \%$ birds $^{-1}$. A study conducted by Tong et al., (2012) showed that Chinese local chicken maintained for 42 days in 12.5 birds $\mathrm{m}^{-2}$ stocking density resulted a carcass weight percentage of $67.29 \%$ ind $^{-1}$. Results from Fathullah et al., (2013) generated the abdominal fat percentage of
$2.38 \%$ birds $^{-1}$ from broiler maintained for 35 days in 10 birds $\mathrm{m}^{-2}$ density. The insignificant effect of different density obtained may be caused by a relatively similar of carcass percentages and bodyweight. It is in accordance with Simitzis et al., (2012) at the density of 6 birds $\mathrm{m}^{-2}$ and 13 birds $\mathrm{m}^{-2}$ that showed insignificant effect, that be caused by no differences in bodyweight and its directly proportional to carcass weight. Daud et al., (2007) stated that the carcass weight percentage is associated to sex, age and bodyweight. The carcass weight percentage increases with the increasing of age and bodyweight. Antari et al., (2015) added that bodyweight gain, feed consumption were eaten and the nutrient content in the feed are factors influencing the carcass weight percentage.

The analysis of abdominal fat percentage among three different density were not significant, it could be caused by a relatively similar abdominal fat percentage and feed provision containing the same nutrients and energy from DOC until 12 weeks. Fathullah et al., (2013) stated that the energy and amino acid level in the diet have the significant effect on abdominal fat. Besides, strain difference and nutritional factors also affect abdominal fat percentage. The abdominal fat percentage produced at very low in this study, allegedly caused by the alive weight which is always increasing. The same finding was reported by Donald et al., (2002) that the alive weight growth, in general, will be followed by. the abdominal fat loss, resulting in the higher meat production. Bell and Weaver (2002) also stated that the abdominal fat percentage ranged between $2.64-3.3 \%$ of alive weight. 
Table 3 Average of carcass weight percentage, abdominal fat percentage, meat, skin, bone percentage (chest, upper thigh, lower thigh) and meat cholesterol at different densities

\begin{tabular}{cccr}
\hline \multirow{2}{*}{ Parameter } & \multicolumn{3}{c}{ Treatment } \\
\cline { 2 - 4 } \% Carcass Weight & $70.26 \pm 2.01$ & $69.72 \pm 0.63$ & \multicolumn{1}{c}{ R3 } \\
\% Abdominal Fat & $1.52 \pm 0.16$ & $1.82 \pm 1.14$ & $1.59 \pm 0.78$ \\
Chest & & & \\
Meat & $22.75 \pm 2.36$ & $22.54 \pm 2.87$ & $20.99 \pm 2.51$ \\
Skin & $2.44 \pm 0.40$ & $2.53 \pm 0.51$ & $2.25 \pm 0.35$ \\
Bone & $4.14 \pm 0.58$ & $4.54 \pm 0.84$ & $4.68 \pm 1.15$ \\
Upper Thigh & & & \\
Meat & $14.66 \pm 0.97$ & $13.85 \pm 0.15$ & $13.68 \pm 0.88$ \\
Skin & $1.65 \pm 0.21$ & $1.53 \pm 0.47$ & $1.48 \pm 0.14$ \\
Bone & $2.37 \pm 0.05$ & $2.42 \pm 0.37$ & $2.49 \pm 0.28$ \\
Lower Thigh & & & \\
Meat & $11.00 \pm 0.45$ & $11.38 \pm 0.91$ & $11.09 \pm 0.59$ \\
Skin & $1.28 \pm 0.19$ & $1.39 \pm 0.06$ & $1.37 \pm 0.27$ \\
Bone & $3.48 \pm 0.39$ & $3.64 \pm 0.70$ & $3.61 \pm 0.24$ \\
Meat Cholestrol (mg per 100g) & $46.65 \pm 12.94$ & $27.97 \pm 11.72$ & $25.82 \pm 6.56$ \\
\hline Description: R1: Stocking density of 8 birds $\mathrm{m}^{-2} ;$ R2: Stocking density of 10 birds $\mathrm{m}^{-2} ; \mathrm{R} 3$ : Stocking density of 12 birds $\mathrm{m}^{-2}$
\end{tabular}

Meat, Skin and Bones Percentage on Chest, Upper Thigh and Lower Thigh. The components in broiler carcass consist of chest, upper thigh and lower thigh composed of meat, skin and bones. Results found the insignificant effect of treatment on percentage of meat, skin and bones of chest, upper thigh and lower thigh (Table 3). The percentage ranges of chest meat, skin and bone are $20.99 \%-22.75 \%, 2.25 \%-$ $2.53 \%$ and $4.14 \%-4.68 \%$, respectively. The percentage ranges of upper thigh meat, skin and bone are $13.68 \%-14.66 \%, 1.48 \%-1.65 \%$ and $2.37-2.49 \%$, respectively. The percentage ranges of lower thigh meat, skin and bone are $11.00 \%-\% 11.38,1.28 \%-1.39 \%$ and $3.48 \%-$ $3.64 \%$, respectively.

The results of the percentage of meat, skin, and bones in the chest, upper thigh and lower thigh KB chickens that do not differ on the density of different enclosure allegedly because the percentage of carcass weight was not affected and also because of the weight difference is small intersection. This is in accordance with the opinion of Haroen (2003) that the achievement of the component pieces of carcass percentage is associated with carcass weight.

Gunawan and Sartika (2001) found the average percentages of $19.79 \%$ at chest, $16.43 \%$ at upper thigh, and $14.40 \%$ at lower thigh. This study shows the higher meat growth than bone and skin. The insignificant effect found presumably because of the insignificant effect of carcass weight percentage and very small difference of slaughted weight. Simitzis et al., (2012) stated the carcass cuts percentage attainment is associated with carcass weight. Muryanto et al., (2002) reported that differences in slaughter weight of $605.3 \mathrm{~g}$ and $812.3 \mathrm{~g}$ did not affect on the ratio of meat, skin and bone, but a large difference of $683.3 \mathrm{~g}$ and $1286.8 \mathrm{~g}$ had a significant effect. Chest is usually used as the meat quality assessment because there is the major component of carcass found (Sari et al., 2014). Argued that, in general, the main factors determining the meat variation are size, sex, body conformation and genetic (Sari et al., 2014). 


\section{Meat cholesterol}

Results indicates the insignificant different cholesterol found at different treatments (Table $3)$. The average of meat cholesterol ranged 25.82-46.65 mg $100 \mathrm{~g}^{-1}$. Study of Syahruddin et al. (2011) showed broiler maintained for 8 weeks with the commercial feed provision in 10 birds $\mathrm{m}^{-2}$ density produced whole meat and skin cholesterol of $73.17 \mathrm{mg} 100 \mathrm{~g}^{-1}$. Results generated by this study showed the lower average percentage of meat cholesterol compared with broiler. Meat cholesterol that is not significant by the density allegedly because of the same feeding of DOC until the end of maintenance. The meat cholesterol reduction in this study showed the mobilization by bile acids synthesized by liver cells, where cholesterol has a precursor compound. Syahruddin et al. (2014) stated that the meat cholesterol reduction occurred as a result of blood cholesterol utilization to synthesize bile. According to Meliandasari et al. (2016), cholesterol level can be influenced by abdominal fat percentage, the lower feed intake and protein intake is low can causes the failure to achieve maximum growth and cholesterol formed in the body is also low. Crude fiber can reduce fat level, so that the fat level in meat may surmise cholesterol decrease.

\section{Conclusions}

The different of stocking densities $(8,10$ and 12 birds $\mathrm{m}^{-2}$ ) did not affect the stress indicators reflected by THI and MDA level, carcass composition and meat cholesterol level. Kampung-broiler crossbred chicken could develop at 8, 10 or 12 birds $\mathrm{m}^{-2}$ densities since the lower of abdominal fat and meat cholesterol resulted.

\section{Acknowledgement}

This research was supported by founding from Indonesia Endowment Fund for Education, Ministry of Finance with Graduate Research
Fellowship grant number PRJ-564 /LPDP.3/2016.

\section{References}

Antari LYS, INT Ariana, and NW Siti. 2015. Pengaruh penambahan probiotik starbio dalam ransum komersial terhadap produksi ayam broiler. Jurnal Peternakan Tropika. 3(2): 259-270.

[AOAC] Association Of Analytical Communities. 2005. Official Methods of Analysis of AOAC International. $18^{\text {th }}$ ed. Assoc. Off. Anal. Chem, Arlington.

Aryanti F, MB Aji, and N Budiono. 2013. Pengaruh Pemberian Air Gula Merah terhadap Performans Ayam Kampung Pedaging. Jurnal Sain Veteriner. 31(2): 156-165.

Asaniyan EK. 2014. Growth performance, feed intake and slaughter characteristics of broiler chicken under three different stocking densities. Journal Animal Production. 1(4): 348-354.

[BPS] Badan Pusat Statistik. 2015. Statistik Indonesia. Jakarta (ID): Badan Pusat Statistik Indonesia.

Bell DD, and Weaver Jr WD. 2002. Commercial chicken meat and egg production. $5^{\text {th }}$ ed. New York (US) : Springer Science and Business Media, Inc. Spring Street.

Daryono BS, I Roosdianto, and HTS Saragih. 2010. Pewarisan karakter fenotip ayam hasil persilangan ayam pelung dengan ayam cemani. Jurnal Veteriner. 11(4): 257-273.

Daud M, WG Piliang, and IP Kompiang. 2007. Persentase dan kualitas karkas ayam pedaging yang diberi probiotik dan prebiotik dalam ransum. Jurnal Ilmu Ternak dan Veteriner. 12(3):167-174..

Donald D, and D William. 2002. Commercial Chicken Meat and Egg Production. $5^{\text {th }}$ ed. Kluwer Academic Publish., California.

Fathullah F, N Iriyanti, and IH Sulistiyawan. 2013. Penggunaan pakan fungsional dalam ransum terhadap bobot lemak abdomen dan kadar kolesterol daging ayam broiler. Jurnal IImiah Peternakan. 1(1):119-128.

Gunawan B, and T Sartika. 2001. Persilangan ayam Pelung jantan $\mathrm{x}$ kampung betina hasil seleksi generasi kedua (G2). Jurnal Ilmu Ternak dan Veteriner. 6(1): 21-27.

Haroen U. 2003. Respon ayam broiler yang diberi tepung daun sengon (albizzia falcataria) dalam ransum terhadap pertumbuhan dan hasil karkas. Jurnal IImiah Ilmu-Ilmu Peternakan 6(1):34-41.

Kgwatalala PM, P Segokgo, and E Simon. 2015. Comparative growth performance of cross-bred (50\% orpington: $25 \%$ australorp: $25 \%$ tswana) and pure-bred tswana chickens under an 
intensive management system. Journal of Poultry Science. Sci. 14(2): 63.

Khan HA, MA Abdelhalim, MS Al-Ayed, and AS Alhomida. 2012. Effect of gold nanoparticles on glutathione and malondialdehyde levels in liver, lung and heart of rats. Saudi Journal of Biological Sciences. 19(4): 461-464.

Kusnadi E. 2009. Perubahan malonaldehida hati, bobot relatif bursa fabricius dan rasio heterofil/limfosit $(H / L)$ ayam broiler yang diberi cekaman panas. Jurnal Media Peternakan. 32(2): 81-87.

Matjjik AA, IM Sumertajaya. 2013. Perancangan Percobaan dengan Aplikasi SAS dan Minitab. Bogor (ID): PT Penerbit IPB Press.

Meliandasari D, B Dwiloka, and E Suprijatna. 2016. Optimasi daun kayambang (Salvinia molesta) untuk penurunan kolesterol daging dan peningkatan kualitas asam lemak esensial. Jurnal Aplikasi Teknologi Pangan. 4(1): 22-27.

Muryanto, PS Hardjosworo, R Herman, and $\mathrm{H}$ Setijanto. 2002. Evaluasi karkas hasil persilangan antara ayam kampung jantan dengan ayam ras petelur betina. Jurnal Animal Production. 4(2): 71-76.

Nikmaram P, MS Yarmand, and Z Emamjomeh. 2013. Effect of cooking methods on chemical composition, quality and cook loss of camel muscle (Longissimus dorsi) in comparison with veal. African Journal of Biotechnology. 10(51): 10478-10483.

Sari ML, FNL Lubis, and LD Jaya. 2014. Pengaruh pemberian asap cair melalui air minum terhadap kualitas karkas ayam broiler. Jurnal Agripet. 14(1): 71-75.

Sarwono SR, T Yudiarti, and E Suprijatna. 2013. Pengaruh pemberian probiotik terhadap trigliserida darah, lemak abdominal, bobot dan panjang saluran pencernaan ayam kampung. Journal Animal Production. 1(2): 157-167.

Simitzis PE, E Kalogeraki, $M$ Goliomytis, MA Charismiadou, K Triantaphyllopoulos, and A Ayoutanti. 2012. Impact of stocking density on broiler growth performance, meat characteristics, behavioural components and indicators of physiological and oxidative stress. British Poultry Science. 53(6): 721-730.

Singh R, KC Murthy, and G Jayaprakasha. 2002. Studies on the antioxidant activity of pomegranate (Punica granatum) peel and seed extracts using in vitro models. Journal of Agricultural and Food Chemistry. 50(1): 81-86.

Syahruddin HAE, E Purwati, and Y Heryandi. 2011. Pengaruh pemberian daun mengkudu (Morinda citrifolia L.) fermentasi terhadap kandungan kolesterol karkas ayam broiler. Jurnal IImu Ternak dan Veteriner. 16(4):266-271.

Tao $X$, and $H$ Xin. 2003. Acute synergistic effects of air temperature, humidity, and velocity on homeostasis of market-size broilers. Transactions of the ASAE. 46(2): 491.

Tong HB, J Lu, JM Zou, Q Wang, and SR Shi. 2012. Effects of stocking density on growth performance, carcass yield, and immune status of a local chicken breed. Journal Poultry Science. 91(3): 667-673.

Wu QJ, ZB Wang, GY Wang, YX Li, and YX Qi. 2015. Effects of feed supplemented with fermented pine needles (Pinus ponderosa) on growth performance and antioxidant status in broilers. Journal Poultry Science. 94(6): 1138-1144.

Zheng XC, QJ Wu, ZH Song, H Zhang, JF Zhang, and LL Zhang. 2016. Effects of Oridonin on growth performance and oxidative stress in broilers challenged with lipopolysaccharide. Journal Poultry Science. 0(0):1-9 